\title{
Poética "neoarábigoandalusa" en el escritor chileno Sergio Macías
}

\author{
Neo-Arabic Andalucian poetics in the Chilean \\ writer Sergio Macías \\ María Olga Samamé B. \\ Universidad de Chile, Facultad de Filosofía y Humanidades, \\ Centro de Estudios Árabes. \\ Correo electrónico: msamame@uchile.cl
}

\begin{abstract}
Sergio Macías ha optado por el autoexilio y porta una esencial tristeza que, al parecer, desea superar en la fuente de inspiración que le ha proporcionado la lírica de los poetas arábigoandaluses Ziryab, Al-Mutamid e Ibn Zaydun, quienes, como él, llevaron una vida de exiliados, en la otrora España musulmana o Al-Andalus. El vate, durante su derrotero, experimentó las frustraciones y penurias de todos los desarraigados, pero, desde que se radicó definitivamente en Madrid, logró transformar estéticamente su exilio y representarlo en una vivencia simultánea: su presente de rebeldía y de pérdida, tamizado por el pasado de aquellos poetas árabes en un escenario de angustia y de quebranto. Nace, así, una poesía donde manifiesta la no pertenencia, el pathos del exilio, la experiencia de vivir en soledad y la sensación de un estado discontinuo del ser.
\end{abstract}

Palabras clave: autoexilio, Al-Andalus, triade, poesía "neoarábigoandalusa", amor, soledad.

Sergio Macías has gone into self-imposed exile and carries within him some special sadness, which, seemingly, he wants to overcome with resort to his sources of inspiration, namely, the lyrics of the Andalucian Arab poets Ziryab, Al-Mutamid, and Ibn Zaydun. Like Macías, these poets lived in exile in Moorish Iberia, also known as Al-Andalus. During his travel into exile, the poet experiences the frustrations and pains of all those who have lost their roots. However, after finally settling in Madrid, he manages to make his exile into an aesthetic transformation and represent it as a twofold experience: his present state of rebellion and loss, sieved through the past of the Andalucian Arab poets in their scenario of anguish and sorrow. Thus, a poetry is born which expresses the state of non-belonging, the pathos of exile, the experience of living in solitude, and the sensation of a discontinuous state of being.

Key words: self-exiled, Al-Andalucian, triad, neo-Andalucian Arab poetry, love, solitude. 


\section{Construcción de UnA POÉtica}

Sergio Macías ${ }^{1}$ pertenece a los escritores chilenos que viven en el exterior, semiignorado por el canon ${ }^{2}$ a pesar de haber desarrollado una fructífera labor literaria, antes y después de la dictadura. Su lírica inicial en Chile evoca espacios de arraigo, reencuentro, experiencias, crisis y rupturas ${ }^{3}$. Más tarde, el rumbo de su escritura, estimulada por el obligado éxodo, deriva en una obra social, política y testimonial ${ }^{4}$. No obstante, la lejanía de la patria añorada restablece en su estro poético la reaparición del mundo lárico y telúrico, transido de dolor, desarraigo, memoria, paraíso perdido. Esta vertiente de nostálgico sentimiento encontrará finalmente su particular registro a través del contacto con la cultura literaria árabe cuando se radique definitivamente en Madrid, adoptando la nacionalidad española.

Su escritura sobre el exilio y la memoria se origina esencialmente en el alejamiento -involuntario, luego optativo- de su tierra y de su pasado, dos factores que agobian y entristecen su existir. Sin embargo, el contacto in situ con la cultura arábigoandalusa y particularmente el cultivo de su literatura, atenúa paulatinamente estas emociones en la medida en que se ilustra con las traducciones del árabe de tres poetas: Ziryab, un exiliado en Al-Andalus ${ }^{5}$, Al-Mutamid e Ibn Zaydun expulsados de Al-Andalus o España bajo dominio musulmán6 .

\footnotetext{
1 Nació en 1938, en Gorbea, IXa Región de la Araucanía. Cursó estudios de Derecho en la Pontificia Universidad Católica de Chile. Fue Secretario General de la Sociedad de Escritores de Chile. Se exilió en México, en 1973, donde trabajó en el FCE; posteriormente, se trasladó a Rostock (RDA), donde fue profesor de literatura hispanoamericana en el Departamento de Lenguas Extranjeras del Instituto Latinoamericano, entre 1974 y 1978 . Actualmente reside autoexiliado en Madrid, donde se desempeña como asesor cultural en la Embajada de Chile. Ha participado en innumerables congresos de escritores y en jornadas sobre hispanismo árabe. Su escritura comprende poesía y prosa. Ha sido traducido a los idiomas árabe, alemán, holandés, italiano y francés. http://www.sergiomaciasbrevis.es/

2 Según él, su pertenencia generacional, por aproximación al año de su nacimiento, 1938, podría ser la del 50 o 60. Sin embargo, debido a su experiencia vital, ha preferido denominarla como 'la generación diezmada', pues quienes la integran han sufrido el exilio. (Ruiz 2004: 30). En un correo electrónico enviado a la autora de este artículo, Macías escribe: “... En todo caso, creo que de todas maneras habría vivido fuera de mi país, a quien amo mucho, pero no le importo. Aquí [España] me publican, tengo críticas, un estudio sobre mi poesía, asisto a congresos de escritores y sobre hispanismo-árabe, y doy continuamente conferencias. Es decir, lo que no me da mi patria... [Hay] antologías sin que yo figure. Me han relegado al olvido, menos en la memoria de mis buenos amigos, muchos de ellos compañeros de ideales. Sin embargo, mis obras han sido presentadas para un Premio Cervantes y también para premios nacionales de literatura en España..."

3 Pertenecen a esta etapa los poemarios publicados en Chile: Las manos del leñador (1969) y La sangre en el bosque (1974).

${ }^{4}$ En Europa ha publicado durante el autoexilio En el tiempo de las cosas (Rostock, Alemania, 1977), poesía; Los poetas chilenos luchan contra el fascismo (Berlín, 1977), antología; Canción de un desterrado (Alemania, 1978), poesía; "La casa como símbolo poético en la obra de Pablo Neruda" (Hungría, 1976), ensayo; Nos busca la esperanza (Holanda, 1979), poesía; Presnie pro Chile (Canciones para Chile) (Checoslovaquia, 1984), antología, entre numerosas obras.

5 Hay varias teorías que intentan explicar el origen de este nombre, como la tesis vándala, la tesis visigótica y la tesis atlántica, siendo la primera relativamente aceptada por los estudiosos de esta etapa histórica de España. Esta señala, grosso modo, que Al-Andalus significa en árabe "tierra de los vándalos", debido al origen de sus habitantes en el momento de la conquista. Al transcribir con la grafía árabe "vándalo", por razones fonéticas se perdió la grafía inicial "v". Por consiguiente, "vándalo" más el artículo determinativo "al", deriva en "al-andalus", con el significado de los "vándalos o la tierra de los vándalos".

${ }^{6}$ La invasión musulmana de la Península Ibérica ocurrió en el año 711. Los árabes gobernaron con el emirato y califato de Córdoba; más tarde perdieron la hegemonía de Al-Andalus, desintegrándose y formando
} 
Este nuevo escenario le permite reflexionar sobre su particular situación de autoexiliado que le permite, de algún modo, contemplarse a sí mismo exteriorizado en la poesía de estos poetas que otrora habían transitado por similar derrotero de expatriación y habían experimentado también el desarraigo del exilio, la angustia de la soledad y estados discontinuos del ser (Said 2005: 184). A través de estos líricos árabes, el escritor chileno percibe que ha encontrado una singular modalidad para restablecer espacios distantes significativos y aquietar su desasosiego interior. Entonces, motivado por esta triade poética, comienza a fluir de su estro un sentimiento de solidaridad colectiva y una necesidad de reconstrucción identitaria en el momento en que reescribe poéticamente el pathos del exilio de estos poetas de Al-Andalus, y que no es otra cosa que la extensión lírica de su desconsuelo y aflicción.

Es preciso recordar que el exilio no es una elección. Sin duda que fueron determinadas circunstancias las que obligaron, tanto al vate chileno como a los tres poetas arábigoandaluses, a vivir en la expatriación. El primero, si bien se queda en España y en un lugar que no le pertenece, finalmente reencuentra un espacio propio en la escritura (Adorno 2001); en cuanto al trío poético, uno se había trasladado a la Península Ibérica atraído por el boato y la estabilidad del Imperio Omeya, mientras que los otros dos andaluses, un monarca y un poeta respectivamente, debieron abandonarla desterrados; no obstante, los tres en su conjunto forjaron su modus vivendi igualmente por intermedio de la escritura y el arte en general.

En efecto, el hogar del poeta chileno autoexiliado deja de ser provisional en la medida en que decide asentarse permanentemente en España, aunque en su fuero interno, debido a las frustraciones y penurias que ha experimentado, continúa sintiéndose prisionero de su desarraigo; cuando asume el extrañamiento de la triade de poetas arábigoandaluses como paradigma de su propia experiencia y, en virtud de su existencia y escritura poética, consigue liberarse y superar gradualmente ese sentimiento de pérdida, de extrema soledad y estados confusos de su ser que subyuga a todo desterrado (Said 2005: 179-185). En esta dimensión, el vate toma conciencia de que vivir en España y en contacto con la historia árabe musulmana le ha permitido adquirir dos culturas que fecundan simultáneamente su numen: una, integrada por el entorno viejo de sus raíces chilenas y, otra, por el entorno nuevo proporcionado por la producción de esta triade poética. Macías se impregna de sus obras ya traducidas, recrea sus vidas como extensión de la propia y, con la libertad que tiene para involucrarse en sus experiencias, construye una poética que se ha denominado en este artículo "neoarábigoandalusa" en la cual “... Hay también una particular sensación de logro conseguido en el hecho de actuar como si uno estuviera en casa dondequiera que resulte estar..." (Said 2005: 195).

Es evidente que este constructo "neoarábigoandalus" está fundamentado en el restablecimiento de experiencias históricas y específicas de esta triade en un momento determinado de sus existencias; por consiguiente. Macías, al recrearlos líricamente, instaura un discurso con una factura exótica y sensual en el cual se propone satisfacer esa anhelada búsqueda identitaria cultural y emotiva como un principio integrador de su pasado irrenunciable que le permite visibilizar, a través de un proceso de escritura, una singular representación de sí mismo con el aporte de imborrables poemas de

las taifas o reinos independientes, hasta el siglo XV. El último bastión árabe musulmán fue el reino de Granada, el cual cayó en poder de los Reyes Católicos, en el año 1492. 
soledad, quebranto, desesperanza y desarraigo; en el decir de Said "La presencia y la ausencia dejan de ser meras funciones de nuestra percepción y se convierten por el contrario en representaciones deseadas por el escritor" (Said 2004, 179).

Desde una perspectiva estructural, Macías construye composiciones que en parte evocan las formas líricas que se cultivaban en Al-Andalus ${ }^{7}$, como la muwashaja, un género estrófico de rima y variada composición temática, y la poesía andalusí con carácter homoerótico masculino ${ }^{8}$. En esta mixtura amolda su inspiración, reformulando una temática afín a esta particular atmósfera, resultando su lírica "neoarábigoandalusa". De este modo, los poemas de Macías se caracterizan porque se dividen en estrofas a veces tituladas, otras numeradas; empleando el dístico, a veces con tono sentencioso, u organizadas en combinaciones de tercetos, cuartetos y quintetos. Emplea, además, el verso libre de breve, mediana y larga extensión, como también inserta, a modo de escenario, algunos arabismos ${ }^{9}$, como "laúd", "rebab", "jarchas", "Alhambra", "cálamo", "azahar"; o nombres propios árabes, verbigracia, "Allah", "Abu Nuwas", "Ziryab", "Ibn Ammar", "Rumaykiyya”. Asimismo, es necesario señalar que Macías reproduce un procedimiento intertextual utilizado en la cultura literaria árabe, esto es la inserción de versos ajenos del autor arábigoandalus que está inspirando su obra. Esta estrategia discursiva -para los árabes, distanciada de todo plagio- se considera un recurso literario legítimo, en la medida en que su modelo sea emulado, el poema goce de originalidad con un profundo sentido estético y, fundamentalmente, que se encomie a su autor ${ }^{10}$.

\section{LA POESÍA "NEOARÁbigOANDALUSA"}

El tema árabe en la producción escritural ${ }^{11}$ de Macías se remonta, sin duda, a las lecturas de Las mil y unas noches que realizó en su juventud, y que reforzó ahora autoexiliado en España, cuando conoció las traducciones de los arabistas españoles de

\footnotetext{
7 En la terminología del arabista Américo Castro, durante los siglos de convivencia entre cristiano, moros y judíos, se cultivó la casida, un género monorrimo, cuantitativo y tripartito con tópicos de amor, panegírico, báquico, cinegético, etc., representativo de la lírica tradicional árabe y preferido por los poetas áulicos; la lírica arábigoandalusa, constituida por la creación y desarrollo de la muwashaja (escrita en árabe), una composición lírica estrófica, con rimas cambiantes, cuya parte final es la jarya (a veces en árabe clásico, o en dialectal andalusí o en romance) y su temática versa sobre el amor, el vino, la ausencia, el lamento, el abandono, entre otras; la muwashaja en árabe dialectal o en romance derivó en el género lírico llamado zéjel. Tanto las muwashajas como los zéjeles eran formas autóctonas y populares. Véase, entre otros, al arabista Emilio García Gómez.

${ }^{8}$ En efecto, entre la corte califal omeya y los reinos independientes de taifas, el neoplatonismo influyó en la creación de la poesía andalusí con carácter homoerótico masculino y femenino, destinado a alabar la belleza de los efebos y las doncellas. Este forma fue estimada como un refinamiento cultural y normal entre la aristocracia árabe. Véase, por ejemplo, a María Jesús Rubiera. 1990. Poesía femenina hispanoárabe. Madrid: Castalia, Teresa Garulo. 1998. Diwan de las poetisas de Al-Andalus. Madrid: Hiperión.

9 Los nombres árabes los transcribimos sin diacríticos.

10 Perromat, Kevin. 2010. "Los viejos antecedentes andalusíes de la intertextualidad y su posible influencia en el occidente cristiano". Revista electrónica de teoría de la literatura y literatura comparada 3: 132-147.

${ }^{11}$ Los siguientes libros contienen poemas árabes sueltos; otros son dedicados a temas de la cultura árabe y arábigoandaluses: Memorias del exilio (1985), poesía; Crónica de un latinoamericano sobre Bagdad y otros lugares encantados (árabe y español, Bagdad, Irak, 1988; en Chile, 1997), poesía; Tetuán en los sueños de un andino (España, 1988), poesía; El hechizo de Ibn Zaydún (Chile, 2001), poesía; El manuscrito de los sueños (España, español y árabe, 2008); Ziryab. El mágico cantor de Oriente (España, 2010), poesía.
} 
la literatura de Al-Andalus. Este saber lo amplió, además, con el del mundo oriental antiguo (Egipto, Mesopotamia). De este modo, estimulado por la temática arábigoandalusa, comenzó a publicar nuevos poemarios, escribiendo con estrategias textuales definidas y con un estilo personal que lo van a consolidar, según la arabista María Jesús Rubiera ${ }^{12}$, como 'el poeta andino de Al- Andalus'. Los primeros indicios con tema árabe referido a la España arábigoandalusa aparecen en poemas sueltos en que se mencionan elementos específicos de esta cultura; verbigracia, el río Guadalquivir, la ciudad de Granada, jazmines, naranjos, luz, huertos, etc.; después, dedicará poemarios completos a esta temática. Así, en Memoria del exilio (1986) se encuentran estos versos alusivos al tema árabe; "[Estuve] En la silla del Moro en medio de una primavera / de jazmines/ de Granada"; y en otro poemario, Noche de nadie (1988), un poema está impregnado de imágenes con un tenue erotismo y comparaciones árabes: "Como el poeta/ que en al Andalus/ tocó el laúd del Guadalquivir,/ cultivo el jardín/ de la memoria./ Como Ibn Jafaya ${ }^{13}$, / labro en los árboles/ la paz de las hojas, y te espero, pastora del amor, sobre el tapiz de la noche". Esta temática también se encuentra en el poemario El libro del tiempo (1988): "Fui viajero del Guadalquivir entre naranjos de luz/ y alondras de orégano. Me arrebujé bajo los limoneros que cantaban en los/ huertos de Sevilla la infancia de Machado...". Asimismo, en varios poemas recreó la herencia árabe en España: “... Peregrinos venidos desde Tetuán./ Conquistadores más allá del desierto/ grabaron el lenguaje de la Alhambra. / Y dejaron sobre el tablero de la tierra/ el ajedrez de la memoria". ("El ajedrez de la memoria", Ruiz 281). Es dable destacar que la cultura mesopotámica igualmente ha sido objeto de inspiración en la escritura de Macías. Así, en el poemario Crónica de un latinoamericano sobre Bagdad y otros lugares encantados (1997) que publicó, luego de participar en el Festival Internacional de Poesía de Marbid ${ }^{14}$, presenta los efectos de la guerra con Irán, pero trascendidos de belleza y dolor en conexión con el encantamiento de la poesía: "Las aguas bíblicas del Tigris/ mecen mis palabras./ Me alivian el sufrimiento/ de sentirme en plena guerra,/ con misiles que caen / sobre el corazón de las palmeras". ("Aguas bíblicas", Crónica... 73). Asimismo, después de recorrer las ruinas de la cultura mesopotámica enclavada entre el Tigris y el Éufrates,

\footnotetext{
12 Véase "Introducción” de María Jesús Rubiera al poemario Manuscrito de los sueños, de Sergio Macías.

13 Ibn Jafaya (1058-1138) fue un famoso poeta y prosista hispanoárabe de la taifa o reino independiente de Valencia. Cultivó el tema descriptivo de la naturaleza, el báquico, el amoroso, entre otros. En la actualidad, ha sido reconocido como uno de los grandes escritores de Al-Andalus. http://www.laie.es/libro/vida-y-obrade-ibn-jafaya-poeta-andalusi/86682/978-84-7517-340-5; http://cvc.cervantes.es/actcult/jardin_andalusi

14 En la década de 1980, Macías viajó varias veces invitado para presentar las lecturas de sus poemas en el anfiteatro de Babilonia, bajo el gobierno de Saddam Husain. En la actualidad, este festival refundado, y a pesar de haber sufrido ciertas interrupciones -como la invasión norteamericana-, se celebra cada año y bajo estrictas normas de seguridad. Participan cientos de poetas nacionales y extranjeros. Se realiza en el Auditorio del Teatro Nacional y en la Casa de la Cultura, en Basra, Irak. El festival incluye, además de las lecturas de poemas, exhibiciones de pintura, fotografía, danzas y presentaciones de libros. Es organizado por los Ministerios de Cultura y de Educación de Irak, con diversos auspiciadores. Este evento literario y cultural tendría como antecedente una herencia de 1400 años; así, por ejemplo, en la época preislámica se celebraba en el mercado de Ukaz, cerca de La Meca, un certamen donde los vates de toda la Península Arábiga se reunían para recitar sus poesías o qasidas. Los poemas ganadores se exhibían escritos en paños de linos con letras doradas y colgados a la entrada del templo de La Kaba: son las mual-laqat o "poemas suspendidos". http://www.rednuestraamericadepoesia.org/festival-de-poesia-al-marbid: http://www.arabespanol.org/cultura/literatura.htm
} 
el escritor exterioriza composiciones líricas con imágenes de Las mil y una noches, La Biblia, héroes épicos, dioses, ciudades antiguas, entre otras $\mathrm{y}$, a veces, con vestigios de su origen sureño: "Están lejos mis amigos,/ los paseos noctámbulos,/ mi vino que iluminaban los astros,/ los cerezos invadidos de luciérnagas,/ las largas lluvias del sur,/ los esteros donde me embriago con el $\operatorname{arrak}^{15} /$ que me ofrecen en la bandeja de Nannar ${ }^{16}$./ Siento mi corazón frágil como una flor./Vuelvo a beber lleno de nostalgia./ Me duermo suavemente bajo una palmera./ Cuando despierto ya es el alba./ La luz derrota mis sueños andinos" ("El viaje", Crónica... 35).

De algún modo, el poeta sobrellevará el autoexilio cuando en varios poemarios incluya, además del tópico de la nostalgia y la soledad, el tema amoroso en una dimensión mítica. Esto se puede observar en El Paraíso oculto (2000) en el cual aparece el tema de la expulsión de Adán y Eva del paraíso, metaforizándolo. El poeta necesita de la figura de la amada y del amor que le prodigue, para que lo proteja, lo guíe y participe de su destino en un cosmos inmutable, donde habita un dios lejano e irascible: “QQuienes somos/ en la simetría del Universo?/ De nuestro amor/ nacieron otros seres/ a imagen y semejanza de la arcilla dolida./ La tierra se fue poblando/ con reinos de infancia,/ ilusiones que conmueven./ Vimos que unos eran buenos,/ pero otros cambiaron la inocencia,/ dejándose llevar por la codicia,/ el crimen, el poder./ Y se olvidaron de la humanidad./ Lloramos con tal fuerza/ que dejamos iniciado el diluvio" (Ruiz 325).

El residir en Madrid no ha sido óbice para que el escritor encuentre otra fuente de inspiración que emana de su resiliencia y experiencia de vida. De esta manera, su nueva identidad poética “... se manifiesta en un movimiento permanente y una búsqueda de equilibrio entre las experiencias del pasado y del presente..." (Nómez 118), es decir, Sergio Macías vuelve a retomar el tema árabe que, en su juventud escritural, había esbozado y, ahora, a través del contacto in situ, adquiere el conocimiento necesario de la cultura literaria arábigoandalusa, creando obras significativas que, de algún modo, contribuirán a la lírica hispanoamericana. La producción que brota de su estro creativo descubre y renueva un arte que había estado reducido a determinadas coordenadas históricas en Al-Andalus. Como hemos señalado, se trata de una poesía singular donde el escritor sintoniza el ámbito telúrico y de destierro, asimilándolos a paradigmas arabeislámicos. En virtud de ellos consigue expresar sus vivencias, liberar las cargas emotivas, apostrofar y exorcizar la soledad y la lejanía. Sin duda, el vate se ha propuesto recuperar, en otros modelos, es decir, inspirado en la producción de la triade arábigoandalusa, aquellas imágenes pretéritas y telúricas, henchidas de sensibilidad y belleza.

En esta perspectiva, se puede aseverar que la predilección de Macías por el tema árabe se debe a que se ha identificado con estas tres figuras literarias procedentes de Al-Andalus y que han experimentado como él la nostalgia y el dolor del destierro. Se produce en el poeta Macías una suerte de sintonización espiritual con la lírica de

\footnotetext{
15 También es conocido como arak, araki, rak en los países árabes y en el Mediterráneo Oriental, India, Sri Lanka, Indonesia, Filipinas. Es una bebida alcohólica destilada, envejecida y con sabor a anís.

16 Nannar para los sumerios y Sin o Zuen para los acadios. Es un dios masculino de la luna, hijo del dios del cielo, del viento y las tempestades o Enlil; se representa como un anciano con cuernos y barba en la mitología mesopotámica. Véase Samuel Noah Kramer. 1978. La Historia empieza en Sumer. Barcelona: Aymá.
} 
aquellos, armonizándola con su experiencia vital, cuyo resultado es una poesía con originalidad en las imágenes, con un sentido decorativo y plástico, acogiendo y adaptando como propia una realidad poética cual orfebre de la palabra ${ }^{17}$. De esta manera, este escritor chileno imbuido de toda esta cultura arábigoandalusa la incorpora a su poesía en un acto luminoso, de admiración y de libertad y, a la vez, como una manera de reescribir la poesía telúrica de sus años mozos, pero en moldes exóticos orientales árabes que lo fusionan e interpretan, sin perder su esencia. La admiración de este escritor por los poetas del Al-Andalus devino en una suerte de hibridismo cultural poético, en el cual la influencia de la poesía árabe, con su sensual lirismo y peregrinas metáforas orientales, va a impregnar su poesía, con ese sentimiento de desarraigo inherente a aquélla padecida por tres autores ${ }^{18}$ : uno desterrado en el emirato, y dos exiliados durante la disgregación del Califato, en la época del Al-Andalus.

\section{El MÚSICO ZiRYAB ${ }^{19}$}

Es reveladora la afinidad artística y espiritual que Macías encuentra en el poeta del Al-Andalus, Ziryab ${ }^{20}$, cuya vida transcurrió en Bagdad, pero más tarde deambuló desterrado por Siria y el norte de África, hasta que se estableció en el emirato de Córdoba. Inspirado en esta figura, el vate Macías publica el poemario narrativo Ziryab el mágico cantor de Oriente ${ }^{21}$, donde desglosa líricamente los escenarios característicos de la existencia desterrada del músico en las cortes bagdadí y andalusí, los cuales, de alguna manera, pueden ser interpretados como una parte simbólica del derrotero del escritor chileno.

17 Cabe recordar que la poesía cultivada en Al-Andalus se caracteriza por seguir los modelos literarios y estéticos de la sociedad arabeislámica urbana cultivados en las épocas omeyas y ab-basidas y la hispanoárabe. Poetiza sobre el tema amoroso galante y udrí o platónico, sobre el tema descriptivo con escenarios interiores donde proliferan los jardines y los palacios, y exteriores donde abundan las escenas cinegéticas, de viajes, bajo un universo estrellado y rodeado por una naturaleza a veces humanizada. También abundan los temas báquicos, elegíacos, panegíricos, nostálgicos, etc.

18 Cada uno será estudiado según su presencia en la historia cronológica literaria de la España Musulmana.

19 Su verdadero nombre era Abu 1-Hasan Ali ibn Nafi. Nació en Bagdad en el año 790 y murió en Córdoba, en el 857. Su sobrenombre, Ziryab, proviene del color de su piel y de su melodiosa voz que recordaban a un pájaro cantor de plumaje negro, similar al mirlo, cuyo nombre en árabe es ziryab.

${ }^{20}$ Algunas fuentes señalan que fue un esclavo de origen negro y liberto a temprana edad. Debido a su talento, ingresó a la corte del califa ab-basí Harun Ar-Rashid (766-809), donde demostró capacidades musicales excepcionales que despertaron la ira, la envidia y los celos de su maestro áulico Ishaq AlMawsili (767-850). Perseguido por su mentor, tuvo que abandonar Bagdad. Subsistió con su familia en algunas cortes sirias y norafricanas. Finalmente, atraído por el esplendor del emirato omeya de España, le escribió al emir de Córdoba, Al-Hakam I (770-822), para ofrecerle sus servicios artísticos. Ziryab llegó a Al-Andalus, precedido por su fama y cuando reinaba el sucesor Abdu Ar-Rahman II (792-852), este le prodigó un palacio y una cuantiosa renta mensual. Su permanencia determinó la bagdadización de la España musulmana para la alta sociedad cordobesa, pues introdujo las modas, los peinados con flequillos, las artes culinarias bagdadíes, las normas sociales, el uso del mobiliario, las copas de cristal, los manteles, etc. En el ámbito musical, implantó las melodías grecopersas, e inventó la llamada música clásica andalusí o la nuba de raigambre norafricana, que posee varios modos o escalas musicales; también le añadió al laúd una quinta cuerda, con un plectro hecho de garra de águila. Se le atribuye la creación del primer conservatorio del mundo islámico.

21 Sergio Macías. 2010. Ziryab el mágico cantor de Oriente. Córdoba: Ánfora Nova. Los poemas sin título son registrados en el índice con las primeras palabras de cada poema. 
Este poema narrativo presenta la naturaleza sojuzgada por el decir del hablante lírico: "Las aguas del Tigris deslumbran de luz./ Un aroma de azahares cubre el antiguo paisaje iluminado/ de mariposas que se equilibran sobre las flores./ Entre higueras y naranjos un músico tañe las cuerdas que desatan/ la alegría de los pájaros sobre el alféizar del horizonte./ Los sonidos del laúd y la dulzura de su voz silencian el ritmo/ de los arroyos que hacen danzar a hojas y nubes". (13). La voz lírica, además, confirma el beneplácito de la divinidad hacia el destino prometedor que anuncia el triunfo del músico: “...Con la llamada del muecín queda absorto en la oración./ Escucha la voz profunda de Allah: - Premio tu fe y perseverancia./ Tus melodías trascenderán y darán armonía al mundo". (14). El lenguaje poético que emplea Macías resume la admiración que le produce la naturaleza, antes singularizada con vocablos sureños, ahora trasplantada con algunos arabismos. Y tal vez se desliza el profundo anhelo del escritor de que sus composiciones logren repercusión en el orbe.

A continuación, el poema narra cómo las composiciones musicales de Ziryab se difunden por el imperio de Harun Ar-Rashid ${ }^{22}$ y, por eso, provocan la ira del maestro Al- Mawsili: "Las gentes que sólo buscan la paz para curar sus tristezas,/ se abandonan a la inmortalidad que les lleva las melodías..../ El maestro Al- Mawsili pasea entre los árboles. Oye/ los suaves arpegios que pregone el viento./... Rojo de ira increpa al joven compositor haciendo huir/ a los súbditos del reino./ -¡Esta es una melodía extraña! Yo no la he enseñado./...Ziryab responde:- Lo aprendí de la naturaleza./ Sólo con la música soy libre, como el poeta con la palabra". (18-19). La insistencia del maestro y los argumentos persuasivos para que abandone las innovadas composiciones, motivan la respuesta de Ziryab que sintetiza su quehacer artístico en comunión con la naturaleza: “...La razón de mis composiciones está en el rumor de las hojas./ En la melodía del agua y en el viaje de las nubes./.... El arte se labra pulcramente con la perseverancia del mar sobre las rocas del silencio./...Me gusta descubrir los misterios. El universo en cada semilla./...(20-24). Y aunque su maestro lo obliga a tocar sus partituras, diciéndole: “...Recuerda que mi ira no perdona la traición” (25), en Ziryab es más intenso el exteriorizar su arte: “... ¡Ay! Deseo perpetuarme como el viento./ Como el fulgor del cosmos./ Como la energía que se despliega al alba./... Vivir para lo que más me gusta: la música que me transporta hacia los cielos./..." (28). Entonces le dedica al califa Harun Ar-Rashid todo su arte: “...toca y canta con la fuerza de la pureza./ Sus composiciones embriagan por la calidez de su ternura./ Las alas se excitan acariciadas por los suaves sonidos/ que producen una paz inconmensurable./" (33-34). En esta dimensión resulta significativa la presencia del maestro Al- Mawsili que representaría el régimen dictatorial y las persecuciones que sufrió Macías previo a su destierro.

Ziryab fue expulsado y obligado al exilio más allá del Tigris, del Éufrates y Egipto: “... Comenzó su andar con un abandono que le pesaba/ como un océano interminable./ Como una montaña de oscuros árboles. Como noche de cenizas./...”(44). Experimenta el dolor, el desarraigo, la melancolía por la pérdida de la tierra natal, pero “...La música y las oraciones mantienen la fortaleza de su ser./..." (49). Subsiste entre beduinos y como pendolista hasta que decide volver a tocar el laúd y cantar: “...Su

${ }^{22}$ Famoso califa de Bagdad, nació alrededor del 766 y murió el 809. Durante su gobierno, el imperio ab-basida alcanzó el máximo esplendor cultural, científico y económico. Fue inmortalizado en la obra Las mil y una noches. 
fama se esparce por los pueblos: Los que llevan tristezas/ se curan con sus tañidos. Sienten la paz de las huríes./" (54). Sin duda que el alejamiento forzoso de Ziryab de su hogar es similar al de Macías, quien se desplazó con su familia hacia México, luego a Alemania para, finalmente, radicarse en España. Estos versos interpretan y mimetizan el desarraigo de ambos: “...Comenzó a conocer otras realidades. Oír diversas resonancias./ Percibir diferentes olores, silencios, poderosas soledades./ A desvariar entre las tormentas del destierro...” (43). “...Difícil es para el desterrado vivir ausente de su país./ Las evocaciones son elegías que se derraman por ríos de sangre..." (45).

Al lucrar con su arte, Ziryab puede comprar dos jóvenes esposas: “... Con ellas comparte sueños, esperanzas, ardores del alma y de la carne..." (56). Su arte se difunde por África y, más tarde, en Al-Andalus, donde reforma la vida palaciega: “....Abder Ramman II [sic] le recompensa con propiedades y abundantes/ sacos de monedas, diciéndole: -Con razón te llaman el mirlo./ Desde ahora Córdoba será tu tierra.-..." /(72). En tanto, cierta analogía se presenta en Macías que sobrevive con sus clases de literatura, conferencias y las publicaciones de sus obras, radicándose en la Península Ibérica. Los poemarios acumulan el depósito de su desasosiego espiritual y profunda soledad que traslada a la voz del hablante lírico: “... Le pesa la soledad,/ el desvelo,/ la nostalgia,/ el silencio de las galaxias./...” (46) “... Sin patria no existe consuelo para la angustia que roe el alma/ y los huesos. Ni para la pobreza que atormenta las entrañas..." (51). Y aunque ha aprehendido y asimilado el otrora esplendor arábigoandalus, el hablante lírico siente "...Bajo la luna su desventura. Abatimiento oculto en el alma. /Se aleja cada vez más de su patria. Su corazón sangra como las amapolas”. (61). Así, Ziryab y Macías se adhieren en un lirismo singular.

\section{El Rey-Poeta Al-Mutamid}

La cultura literaria arábigoandalusa le proporcionó a Macías otra figura que le ha permitido reescribir su vida agobiada por el dolor del desarraigo y la soledad entremezclada con elementos de la naturaleza, pero con moldes exóticos orientales árabes que lo fusionan e interpretan sin perder su esencia. En efecto, inspirado en el rey-poeta de Sevilla Al-Mutamid (1040-1095) publica El manuscrito de los sue$\tilde{n} o s^{23}$, un poemario con carácter narrativo, que se estructura a base de treinta y seis poemas y un epílogo. La trama es la historia de amor del rey Al-Mutamid y su esclava Rumaykiyya (Itimad cuando se convierte en su esposa), más el tema del despecho del amante del soberano, el poeta Ibn $\mathrm{Ammar}^{24}$, el cual se debate entre los celos, el odio y la soledad, para morir, finalmente, a manos del rey. También los amantes terminan con un destino fatal: marchan a Agmat (Marruecos) al destierro, donde todo es dolor, nostalgia y muerte.

\footnotetext{
23 Sergio Macías. 2008. El manuscrito de los sueños. [Cádiz]-España: Viprén. Edición en español y árabe, con comentarios críticos e ilustraciones. Los poemas están numerados del 1 al 36, más el epílogo.

${ }^{24}$ Ibn Ammar (1031-1086), cuyo nombre completo era Abu Bakr Muhammad Ibn Ammar, también conocido como Ibn Ammar de Silves o Abenamar, fue un poeta arábigoandalus y visir de la taifa de Sevilla, del cual era rey Al-Mutamid y con quien mantuvo un romance. También participó en diversas intrigas políticas y el soberano, a la postre, lo asesinó. Se dice que Al-Mutamid tenía harenes masculinos.
} 
El poemario se inicia con la descripción de Sevilla que realiza el hablante lírico, la ciudad-escenario del rey y su historia. Traza un ambiente árabe, colmado de imágenes sinestésicas y prosopopéyicas: "Los almendros encendidos por el sol/ destilan el fuego del día./ El rumor de los arroyos/ atraviesa el ojo del tiempo./ Los dedos de la brisa/ tocan el arpa de los sauces./Y el corazón de Sevilla/ se abre como rosa de luz". ("1", Macías11). También describe el escenario de amor del amante del rey de triste desenlace: “...Crece la pasión del amante/ forjada en la fragua de los pétalos./ Bajo la almohada de la hierba/ late el corazón de la tierra./ Ibn Ammar extiende su manto de oro/ para que la luna anide la ternura. Limpia los labios del monarca/con el agua misteriosa del rocío./Y peina los frágiles cabellos/ con ramitas de primavera”. (“4”, Macías 14-15). El amor entre ambos está enmarcado en una idílica naturaleza: “... El amor se anida bajo el árbol del tiempo/ cuando las margaritas bordan lagartijas/ en los pañuelos de la hierba./Y la noche cubre con su manto de estrellas/ el hermoso cuerpo del poeta-guerrero./ Vela sus sueños el fiel Ibn Ammar,/ mientras la melodía del agua/ fluye entre murallas vegetales". (“6”, Macías 18). La pasión se interrumpe para siempre cuando aparece la esclava Rumaykiyya ${ }^{25}$, cuya belleza congrega algunas metáforas y comparaciones tradicionales árabes: "Los amantes caminan a orillas del río/ seducidos por los aromas,/ las palabras siderales, / la paz de los mimbres./ Entre un oleaje de salvias/ surge la esclava Rumaykiyya./ Danza sobre tapices de flores./ Su voz es suave como la brisa/ que embriaga a los manzanos./ Frágil como la tórtola/ alhajada de luz./ La tejedora del sol/ tiene ojos de almendra,/ y suave andar de gacela..." ("7", Macías 19-20). El rey y su esclava inician su romance, en una dimensión cósmica, lumínica, paradisíaca: “...se aman entre viñedos de astros./ Se derrama la luz/ sobre los azahares/ y el gozo queda/ en la melodía de la floresta./ Los murmullos de los juncos/ rememoran el paraíso de las corolas/... De la boca del poeta/ fluyen jarchas ${ }^{26}$ de amor,/ que cantan los pájaros/ sobre las filigranas del horizonte..." ("10", Macías 24-25). En tanto, Ibn Ammar, el amante dolido y rechazado, es condenado al olvido. Entonces el amor por su rey se convierte en despecho, venganza y odio, pues proclama a la ciudad su secreto idilio. Es condenado a prisión y asesinado por el soberano, poseedor de una potencia cósmica: “...El amante cincela su angustia/sobre los cálices de las rosas./ En el minarete de las estrellas,/ se desgarra en aullidos de soledad./ El despecho hiere el alma/ alimentada con dulces canciones ...Blasfemia y venganza/ contra el que en un tiempo/ le hizo conocer el encanto/ las ansias, los delirios... Escupe la hiel detenida de la amargura./...Y selló su destino para siempre,/ en las mazmorras de al-Mubarak./...El rey-poeta acude/ con su hacha de astros,/ forjada en las batallas de al-Andalus./ La entierra entre las vigas de la sangre./..." (“18”, "21", “29”, Macías 37- 39, 43 y 58). Embelesado por la pasión, el rey-poeta Al-Mutamid

\footnotetext{
25 Al-Mutamid conoció a la hermosa esclava Rumaykiyya o Itimad cuando esta improvisó unos versos inconclusos que el poeta áulico y favorito del soberano, Ibn Ammar, no completó. Al-Mutamid la hizo su esposa y satisfizo todos sus caprichos, algunos de los cuales fueron recreados en el Libro de Patronio o Conde Lucanor, del Infante D. Juan Manuel (v. g., véase el enxemplo XXX). Más tarde, junto a sus hijos, acompañó al rey al exilio. Ambos están sepultados en Agmat. Véase Adolf Friedrich von Shack. 1988. Poesía y arte de los Árabes en España y Sicilia. Madrid: Hiperión. "Al Mutamid”, capítulo X : 159-192. También en: http://www.poetasandaluces.com/autor.asp?idAutor=23, http://www.islamicspain.tv/AndalusiSociety/WomenofAl-Andalus.htm

26 Composición lírica ubicada al final de un poema estrófico llamado muwashaja. Está escrito en lengua árabe culta. Versa sobre el amor, la ausencia, el cautiverio, la nostalgia. el vino, el alba, entre otros temas.
} 
continúa amando a su esclava, a quien le dedica versos que parecieran fusionarse con el decir del propio hablante lírico: “... Soy el hombre del Sur, / que se consume en tu sonrisa./ Alegría que fluye de tus ojos de gacela./ Mis versos están tejidos por los arco iris./Y mi amor por tu cuerpo de mariposa". ("20", Macías 42). La naturaleza se erotiza ante la pasión de los amantes: "Las flores derraman/ su semen de luz/ sobre el vientre de la tierra./ El rey-poeta cubre a su amada,/ con besos como pétalos de rocío./ Descarga sus placeres/ con la eficacia de las mareas./...” (“24”, Macías 47). Sin embargo, un sueño premonitorio del rey amenaza el futuro de la pareja: "Pero ese día el amado soñó/ que una oscuridad le invadía,/ bajo las alas negras de los cuervos/y caballos de luna despavoridos./ Perros destripaban a los astros./ Búhos del insomnio/ se perdían en el vacío./ Mientras las cenizas del cielo,/ ahogaban el esplendor de los escorpiones”. (“32”, Macías 63) 27. El poemario muestra al hablante lírico solidarizando con el dolor y la nostalgia del expulsado de su amada tierra: "Convertido en esclavo/ marcha al destierro./ Le acompaña Rumaykiyya./ Todos se inclinan ante su bravura./ Lleva el León de Oriente/ furia y pesar en el corazón,/ y gumías ${ }^{28}$, de nieve en el cabello"...."Recuerda su infancia en Silves./ Huertos con pájaros como lirios./ Las mejillas de las amapolas./Árboles que deslizan el rocío...” “...Camina engrillado/ bajo la tristeza de su pueblo./ Entona la melodía de los naranjos./ lleva en su rostro el orgullo del olivo./ En los campos de África/ mira los vuelos libres /de perdices y tórtolas...”. (“33”, “34”, “35”, Macías 66-69).

El título, El manuscrito de los sueños, interpreta y metaforiza el propósito del autor chileno de entregar una arquitectura poética de sustantivos y adjetivos emanada del conocimiento de algunos escritores arábigoandaluses. Asimismo, este poemario se caracteriza por una novedosa recreación estética verbal, con la cual se describe la existencia apasionada y dramática de un rey-poeta que, como el autor Macías, sufrió el destierro. Las representaciones de la naturaleza, alejadas de la otrora metáfora y comparaciones telúricas, se enmarcan en la herencia poética adquirida por el autor, al construir singulares imágenes, con énfasis en la referencia lumínica ('encendidos por el sol', 'antílopes de luz'); en las arbóreas ('brazos de los limoneros', 'perfume de los acacios'); en las herbáceas ('oleaje de salvias', 'piel de campánula'); en las florales ('temblor de los narcisos', 'fragua de los pétalos'); en las frutales ('ojos de almendra', 'viñedos de astros'); en los animales ('nidos de palomas de arena', 'búhos de luna'); en lo acuoso ('arpegios del río', 'mar de las penas'); en lo sensual ('los senos azules del día', 'su semen de luz'); y también en el uso de algunos arabismos, asida $^{29}$,'abu qalamun' ${ }^{30}$, chilaba $^{31}$, mizmar $^{32}$, gumía, entre otras.

\footnotetext{
27 En efecto, la historia señala que Al-Mutamid fue derrotado en la batalla de Sagrajas, en 1086, y depuesto por sus hermanos de etnia y cultura, los almorávides, y desterrado en el 1090, con toda su familia a Agmat, importante ciudad medieval bereber, ubicada al sur de Marruecos.

28 Un arma blanca similar a una daga un poco encorvada, que usan los moros.

29 Masa de harina con trigo cocido.

${ }^{30}$ Literalmente significa "padre de la pluma", y se puede interpretar como "destreza en la escritura, en la creación literaria".

31 Pieza de vestir con capucha que usan los moros.

32 Instrumento de viento parecido a una flauta.
} 


\section{IbN Zaydun, EL POETA AMANTE y OLVIDAdo}

Coincidencias temáticas con el poemario anterior se encuentra en el libro $E l$ hechizo de Ibn Zaydun ${ }^{33}$ con el subtítulo "Una historia de Al-Andalus". La trama está centrada en la vida de un poeta cortesano, Ibn Zaydun ${ }^{34}$, y las consecuencias de

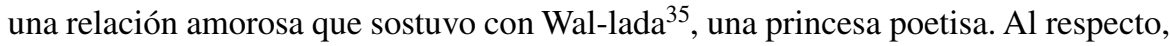
Teresa Garulo señala que esta escritora, además del tema amoroso, cultivó el tema satírico "con cierta asiduidad", en contra de sus amantes (143). Cuando el escritor chileno obtuvo información de la vida y obra de Ibn Zaydun, le produjo sin duda una nueva impresión, principalmente por el tema del destierro, el tratamiento poético del amor y el singular rol que desempeña la naturaleza, exhibida en íntima armonía con las emociones y la sensibilidad del poeta hispanoárabe. Macías ha dicho de Ibn Zaydun y, tal vez de sí mismo, en el prólogo de esta obra:

“...De esta situación emocional [el destierro] surge su valiosa poesía de amor y soledad. También testimonial, imaginativa, fatalista, metafórica, hermosa, nostálgica, pasional y conmovedora. La memoria trabaja en función del recuerdo que está determinado por el sentimiento. Y éste hace surgir la imagen de la amante perdida pero no olvidada. El ideal poético es siempre el amor... Los recuerdos se entrelazan con la patria telúrica, de ellos se sirve el autor para describir también la región del espíritu ante la lejanía del ser amado. El poeta desdeñado se enfrenta al confinamiento, a un mundo donde le invade la soledad..." (Macías 5).

El poemario consta de cuarenta y seis poemas numerados, en verso libre y de breve extensión. Sirven de escenario la ciudad de Córdoba y el río Guadalquivir. El hablante lírico, aunque distanciado en la tercera persona, se integra a este espacio con las imágenes recurrentes que expresan su vínculo y el de Ibn Zaydun con la naturaleza idílica: "Miró hacia los astros/ que caían como luciérnagas/ sobre la piel de los jazmines./ Tejió su poesía/ en la rueca del aire./ El corazón deliraba/ de juventud y placer/ por su amada Córdoba./Y la luz se destrenzaba/ sobre el río Guadalquivir". ("1", Macías

\footnotetext{
33 Sergio Macías. 2010. El hechizo de Ibn Zaydun. Valparaíso-Chile: Academia Iberoamericana de Poesía.

${ }^{34}$ En rigor, su nombre completo era Ahmad Ibn Abdu Allah Ibn Ahmad Ibn Galib Ibn Zaydun (Córdoba 1003-Sevilla 1073). Recibió una esmerada educación, estimulada por su talento para versificar. Se hizo famoso por una elegía que dedicó a la muerte de un juez. Su vida trascurrió en distintas cortes de Al-Andalus. Cuando llegó a Córdoba, enamoró a la princesa y poetisa Wal-lada, hija del califa omeya Muhammad III, al Mustakfi, que pertenecía a la sociedad de escritores y sabios. Se hicieron amantes e intercambiaron apasionados requiebros amorosos, hasta que Ibn Zaydun se prendó de Amina, una hermosa esclava negra. Iracunda y despechada Wal-lada enamoró a un poeta menor, Ibn Abdus, e Ibn Zaydun, acusado de intrigas, fue encarcelado. Más tarde logró la libertad, pero fue desterrado. Recorrió varias cortes, quedándose bajo el amparo de Al-Mutadid, padre de Al-Mutamid. Este poeta se destacó por innovar el tema amoroso hispanoárabe, a través de la simbiosis neoplatónica y erótica.

35 Wal-lada bint Al-Mustakfi (Córdoba 994-1091), princesa andalusí hija del califa Muhammad Al-Mustakfi y de una esclava cristiana. Su vida transcurrió inmersa en la inestabilidad política, previa a la caída del califato. Fue única heredera, de gran belleza, soltera, enamorada y protectora de las letras. En el palacio inauguró una academia para vates de ambos sexos. Adelantada a su época, no usaba el velo, y participaba en certámenes literarios.
} 
9). En otro poema no deja de omitir que "Córdoba lozana"36, plena de olores, ha sido un centro de la actividad intelectual y estética de Al-Andalus: "El poeta canta a los olivos,/ al aroma de azahar./Y se refugia enmudecido/ para soñar junto a un surtidor/ en el templo de las flores./ El pensamiento se hace luz/ en la geometría cósmica./ La filosofía del silencio/ crece en la floración de los naranjos” (“2”, Macías 10). Luego, la voz lírica presenta al poeta que se ha nutrido y embriagado poéticamente de esta tierra andalusa: "Ibn Zaydun no puede vivir/ sin su tierra de cereales./ Ni los ojos fulgurantes/de los pájaros de al- Andalus"... "Él se embriaga con el vino/ que fluye como río por la sangre./ Siente el ardor misterioso/ de las uvas rutilantes./ Escribe con tinta de jacintos/ sobre la floración del Sur..." (“3” y "5", Macías 11-13). También la voz lírica convoca la música con sus emociones y seres paradisíacos musulmanes: "Ibn Zaydun toca el laúd/ sobre el monte de los luceros./ En el cielo danzan/ las huríes ${ }^{37}$ seducidas./ La orquesta sideral/alegra la breve existencia". ("10", Macías 18). Asimismo, los habitantes de Córdoba se sienten embelesados con los poemas de su aedo. En el siguiente ejemplo, el autor Macías hace uso de la intertextualidad al insertar un poema del propio Ibn Zaydun. Así, el hablante lírico señala que el poeta es distinguido por su audiencia: "Los ciudadanos le piden $\operatorname{casidas}^{38}, / \mathrm{y}$ él deja que su ilusión les deleite:/"Cuántas veces pedí vino a una gacela/ y ella me ofrecía vino y rosas,/pues pasaba la noche libando/el licor de sus labios/y cogiendo rosas en su mejilla”. ${ }^{39}$ ¡Ah! El verbo fluye incontenible/ de ánfora de los sueños”....(“12”, Macías 20). Como se indicó anteriormente, la inserción de versos ajenos en la obra de un autor era una modalidad aceptada y utilizada en la literatura árabe clásica, pues indicaba la admiración y el tributo que el vate sentía y homenajeaba la obra del imitado. Similar actitud se presenta en Macías con respecto al poeta Ibn Zaydun.

Instalado este escenario, el poeta cordobés se siente atraído hacia la figura de la princesa Wal-lada, y le dedica sus composiciones líricas, pues ella es "La hija del califa omeya al-Mustakfi/ es más hermosa que todas las flores./ Se llama Wal-lada. Gacela de las auroras./ Él la ahoga con el fuego de su mirada./ Nunca fue tan feliz el poeta al sentirse/ hechizado por la imagen y la palabra". ("13", Macías 21). La princesa también compone poesía y su creación lírica puede establecer una conexión entre lo cósmico y la naturaleza: "Ella escribe versos/ con dedos de luna./ Reflexiona sobre la materia,/ la dulce brisa/que acaricia a los naranjos./ Las luces del cielo/ iluminan tenuemente/ los líquenes del crepúsculo". ("15", Macías 23). Este espacio atemporal, pleno de elementos vegetales y siderales, permite que florezca la pasión de los amantes: "El delirio del amor/ no tiene límites./ El tacto del tiempo/ no existe./ La juventud se desborda/ bajo el manto de la belleza... Reina la pasión en los ojos del olivo/...El aire huele a alhucemas./ El gozo se cubre con el azul/ deslumbrante de la Vía Láctea...” (“17” y “18”, Macías 25-26). Pero, del mismo modo, es la naturaleza

\footnotetext{
36 Título de un poema de Ibn Zaydun y que el autor Macías inserta como parte de un verso en el poema "8”, que dice “...De vivir en su Córdoba lozana./ En la belleza de su pueblo iluminado". (Macías 16). En rigor, todo este poemario emplea algunos intertextos de la poesía de Ibn Zaydun.

37 Son mujeres hermosas, jóvenes, aromáticas, sin velos y eternamente vírgenes, que prodigan sexualmente a los verdaderos creyentes en el Paraíso musulmán.

38 Esto es, poema árabe clásico, monorrimo, cuantitativo y tripartito. En árabe se llama qasida.

39 Ibn Zaydun. 1979. Poesías. Madrid: Instituto Hispano-Árabe de Cultura, Edición bilingüe árabe español. El poema inserto se titula "Vino y rosas", p. 47.
} 
la que anuncia la separación de los amantes con la llegada de la esclava Amina, cuya belleza negra obnubila al poeta: "En un día de ansiedades,/ de pájaros fugitivos./ De colibríes perdidos/ en el jardín de las rosas/ una nube oscura cubre/ al poeta conmovido/ por la fugacidad de las hojas..." (“19”, Macías 27) El hablante lírico realiza una pintura de "Amina, la de los ojos grandes,/ donde cabe todo el firmamento...". "Tiene cuerpo grácil/ como Antílope de sol..." “...La hermosa figura/ contiene el misterio/ y el ardor de su raza oscura...” (“20”, “21”, “22”, Macías 28-31). De nuevo se presenta la intertextualidad, pues el hablante lírico, fusionado con esta traición amorosa, inserta versos que el poeta Ibn Zaydun había dedicado a su amada: “... Sólo queda el verso para Wal-lada: "Aquella muchacha de ojos bellos,/de fragancia deliciosa,/de aliento perfumado,/ de aroma penetrante,/ me tendió su fina mano, y comprendi/ que era hermosa mujer/ de mirada seductora..." 40 . La pasión desborda a Ibn Zaydun, pues ama intensamente a Amina, olvidando a su amada princesa: “...El cuerpo azabache/ se refugia tembloroso/ entre los arcos de sus brazos"... "Incapaces de poner límite al deseo,/ la pasión elevó el fuego misterioso/ que reina en las adelfas./ Wal-lada sorprende a su amante/ en el lecho de la esclava...." ("28”, "29”, Macías 28 y 30). El poeta arrepentido busca el perdón, pero “...De la alegría cae al abandono./ Se cubre con la túnica de la soledad..." "Sus batallas por recuperarla/ le acercan a la muerte...” (“30”, “32”, Macías 38 y 40). La princesa Wal-lada busca otro amante y transforma su amor en odio y venganza, a pesar del arrepentimiento del poeta, quien, a la postre, es encarcelado y luego desterrado: “...No hay compasión/ para su dolor herido./ Ella en el despecho/ busca a un ambicioso visir/ para curar su herida". ("32", Macías 40). Al poeta encerrado y aquejado únicamente lo consuela el rumor de la naturaleza exterior. El poema termina con otra intertextualidad: "Enviado a prisión y al olvido/ sigue soñando con Wal-lada"... "El poeta oye la brisa/ que despierta a los árboles...En su delirio canta: Oh tú que has cortado/ los lazos de mi amor,/ y has desatado/ los lazos de mi abandono". (“33”, “34”, Macías 41-42) ${ }^{41}$. Se dirige a Sevilla, desterrado, donde trascurre su dolorosa vida hasta su muerte. Según una leyenda, su alma ha estado eternamente ligada al amor verdadero y sincero que sintió por Wal-lada. En este sentido, los poemas que describen esta última etapa de Ibn Zaydun interpretan el sentir de todo exiliado, como es el autor de este poemario y, tal vez, Wal-lada sea, además del amor, la patria querida y añorada: “...El destierro le arranca de sus raíces./ Su identidad se pierde en el horizonte./ El hombre sólo es feliz/ cuando se funde con su tierra". "No hay peor sufrimiento/ que las cadenas del exilio./ Nada conforma el desarraigo./ La condena a sobrevivir/ en un paisaje extraño..." “... Como sauce solitario,/ languidece su cuerpo,/ hacia donde se silencian las raíces...". (“36”, “38”, “39”, Macías 44, 46 y 47).

Las imágenes están a tono con el dolor y el exilio y nuevamente el universo solidariza con su tristeza. Finalmente, cuando Ibn Zaydun ya ha muerto, su alma vuela al huerto de Córdoba y se convierte en leyenda, junto a su amada: "A esta hora los diamantes del cielo/ se encienden como cirios./ Un hombre y una mujer se encuentran/

\footnotetext{
40 Ibn Zaydun. Op. cit. Se trata de una parte del poema titulado "Tras la ausencia", p. 49. Nótese que ambos poetas mencionan algunos de los rasgos típicos de una mujer ideal, donde el cuerpo es objeto de comparación.

41 Ibn Zaydun. Op. cit. Macías inserta los dos primeros versos del poema "Si tú sintieras por mí...", p. 77.
} 
entre las arboledas del silencio...”. (“46”, Macías 54). Este poemario permite una vez más al autor Macías no solo recuperar su compromiso con la naturaleza, sino también proyectar su sentimiento como desterrado de su Chile natal.

\section{CONCLUSIÓN}

La opción del escritor Sergio Macías por vivir el autoexilio en España le ha permitido ponerse en contacto con la lírica arábigoandalusa, introduciéndolo en un mundo nuevo de expresividad y belleza, conforme con aquella que había expresado en sus poemarios láricos y telúricos de otrora. $\mathrm{Al}$ asimilar el legado de la cultura literaria de los árabes de Al-Andalus no hizo más que hacer suyo, por afinidad espiritual y sensorial, el derrotero de quienes cantan con nostalgia y añoranza a su tierra amada. Su particular poesía afín a la triade manifiesta la no pertenencia, el pathos del exilio, la experiencia de vivir en soledad y la sensación de no haberla superado.

\section{OBRAS CITADAS}

Fuentes primarias

Macías, Sergio. 1986. Memoria del exilio, Madrid: Instituto de Cooperación Iberoamericana. —. 1988. Noche de nadie. Madrid: Poesía ambos mundos.

1988. El libro del tiempo. Elche-España: Caja de Ahorros del Mediterráneo. 1989. Tetuán en los sueños de un andino. Madrid: Betania.

- 1997. Crónica de un latinoamericano sobre Bagdad y otros lugares encantados. SantiagoChile: Talleres Gráficos de Impresos Universitaria. (Publicado en árabe en Bagdad, Irak, 1988).

- 2000. El paraíso oculto. Chile: CESOC.

—. 2001. El hechizo de Ibn Zaydun. Santiago-Chile: Academia Iberoamericana de Poesía.

—. 2008. El manuscrito de los sueños. Chiclana de la Frontera [España]: Fundación Viprén /Alograf. (Bilingüe español-árabe).

— 2010. Ziryab el mágico cantor de Oriente. Córdoba: Ánfora Nova.

\section{Fuentes secundarias}

Adorno, Theodor. 2001. Mínima Moralia: reflexiones desde la vida dañada. Madrid: Taurus.

Al-Mutamid. 1979. Poesía. Barcelona: Bosch. (Traducción y comentario de Miguel José Hagerty.

Corriente, Federico. 1991. Diccionario árabe-español. Madrid: Herder.

García Gómez, Emilio. 1940. Poemas arábigoandaluces, Madrid: Espasa-Calpe.

Garulo, Teresa. 1998. Diwan de las poetisas de al-Andalus. Madrid: Hiperión. 2009. "La biografía de Wallada, toda problemas". Anaquel de Estudios 20: 97-116.

Ibn Zaydun. 1979. Poesías. Madrid: Instituto Hispano-Árabe de Cultura. (Edición y traducción del árabe de Mahmud Sobh).

García Gómez, Emilio. 1990. Las jarchas romances de la serie árabe en su marco. Madrid: Alianza. 
García Sanjuán, Alejandro. 2003. "El significado geográfico del topónimo al-Andalus”, Anuario de Estudios Medievales 33/1: 3-36.

Guichard, Pierre. 1995. Al- Andalus. Estructura antropológica de una sociedad islámica en Occidente. Granada: Servicio de Publicaciones de la Universidad de Granada.

Kramer, Samuel Noah. 1978. La Historia empieza en Sumer. Barcelona: Aymá.

Marín, Manuela. 1992. Individuo y sociedad en Al-Andalus. Madrid: Mapfre.

Nómez, Naín. 2010. "Exilio e insilio: representaciones políticas y sujetos escindidos en la poesía chilena de los setenta”. Revista chilena de literatura 76: 105-127.

Perromat, Kevin. 2010. "Los viejos antecedentes andalusíes de la intertextualidad y su posible influencia en el occidente cristiano". Revista electrónica de teoría de la literatura y literatura comparada 3: 132-147.

Reina, Manuel Francisco editor. 2007. Poesía andalusí. Madrid: Edaf.

Rubiera Mata, María Jesús. 1992. Literatura hispanoárabe. Madrid: Mapfre. (También en edición digital, Biblioteca Virtual Miguel de Cervantes. 2001).

-1988. La arquitectura en la literatura árabe. Madrid: Hiperión.

—. 1990. Poesía femenina hispanoárabe. Madrid: Castalia.

Ruiz, Remo. 2004. El paraíso habitable. Introducción a la poética de Sergio Macías. CádizEspaña: Vipren.

Said, Edward. 2005. Reflexiones sobre el exilio. Barcelona: Debate.

- 2004. El mundo, el texto y el crítico. Barcelona: Debate.

VV. AA. 1960. Encyclopédie de l'Islam. Leyde. E. J. Brill, Paris: G.-P. Maisonneuve Max Besson, tome I, A-B, “Al-Andalus": 501-519.

1975. Encyclopédie de l'Islam. Leyde: E. J. Brill, Paris: G.-P. Maisonneuve \& Larose, tome III, H-Iram. "Ibn Ammar": 727-728.

—. 1975. Encyclopédie de l'Islam. Leyde-Paris: E. J. Brill, G. P. Maisonneuve \& Larose, tome III, H-Iram. "Ibn Zaydun": pp. 998-999.

—. 1993. The Encyclopaedia of Islam. Leiden-New York: E. J. Brill, volume VII, Mif-Naz. "Al-Mu'tamid": 766-768.

—. 2002. The Encyclopaedia of Islam. Leiden: Brill, volume XI, W-Z. "Ziryāb": 516-517.

Von Schack, Adolf Friedrich. 1988. Poesía y arte de los árabes en España y Sicilia. Madrid: Hiperión. 